\title{
Photoperiodic Control of Flowering in Seed-propagated Begonia ×tuberhybrida Voss.
}

\author{
Meriam G. Karlsson and Jeffrey W. Werner \\ Department of Plant, Animaland Soil Sciences, University of Alaska-Fairbanks, \\ Fairbanks, AK 99775-7200
}

Additional index words. tuberous begonia, rate of development

\begin{abstract}
Plants of Begonia $\times$ tuberhybrida Voss. 'Nonstop', 'Clips', and 'Musical' were exposed to $0,1,2,3$, or 4 weeks of short days (SD, 9-hour daylength) initiated at 0,4 , or 8 weeks following germination. Plants grown under long days (LD, 16-hour daylength) flowered 68 ('Musical'), 78 ('Clips'), or 83 days ('Nonstop') after germination. Exposure to SD delayed flowering in all three cultivars. The delay in 'Nonstop' and 'Clips' was independent of plant age at time of SD exposure. One to 4 weeks of SD delayed flowering 11 to 14 days in 'Nonstop'. In 'Clips', the delay in flowering increased linearly from 7 to 19 days with increasing duration of SD. Flowering was delayed up to 15 days in 'Musical' when SD were begun 0 or 4 weeks after germination. Exposure to SD during the final 4 weeks of development did not affect flowering in 'Musical'. Exposure to SD did not affect shoot, leaf, or flower number in any of the cultivars. The root/shoot dry-weight ratio within cultivars was independent of daylength.
\end{abstract}

The seed-propagated tuberous begonias have uniform growth over a wide range of environmental conditions and semi-double flowers in many pleasing colors. 'Nonstop' was the first seed-propagated cultivar of Begonia $\times$ tuberhybrida Voss. introduced during the 1970 s by Benary Seeds of Germany (Ewart, 1985). Many additional seed-propagated cultivars are now produced commercially. The group of tuberous begonias propagated by seed is still, however, commonly referred to as the Nonstops.

Tuberous begonias reportedly produce tubers under short days (SD) and low temperatures (Djurhuus, 1985; Ewart, 1985; Fonteno and Larson, 1982, 1983; Oloomi and Payne, 1982; Peters 1974; Tonecki, 1986), but in contrast with $B$. Xhiemalis Fotsch (hiemalis begonia, rieger begonia, or elatior begonia), continuous long days (LD) and temperatures $>17^{\circ} \mathrm{C}$ are required for proper plant development and flowering (Ewart 1985; Kaczperski et al., 1989). Short-day conditions may result in delayed development and dormancy, although seed-propagated tuberous begonias may respond differently to photoperiod than cultivars propagated by tubers. This study was initiated to determine and compare the effects of photoperiod on rate of development and morphological characteristics of three cultivars of seed-propagated tuberous begonia.

Received for publication 2 May 1997. Accepted for publication 1 Sept. 1998. We appreciate the financial support from the American Floral Endowment. The cost of publishing this paper was defrayed in part by the payment of page charges. Under postal regulations, this paper therefore must be hereby marked advertisement solely to indicate this fact.

\section{Materials and Methods}

The cultivars Nonstop Orange, Clips Orange, and Musical Orange were selected for the study. Two seeds were sown into each 10 $\mathrm{cm}(800 \mathrm{~mL})$ pot filled with a peatlite medium (Sunshine Mix \#1; SunGro Horticulture Inc., Bellevue, Wash.) on 2 Feb. Germination occurred at 21 to $24^{\circ} \mathrm{C}$ media temperature under continuous light $\left(100 \pm 10 \mu \mathrm{mol} \cdot \mathrm{m}^{-2} \cdot \mathrm{s}^{-1}\right)$. Two weeks after seeding, the seedlings were thinned to one per pot, 180 pots with uniform seedlings of each cultivar were selected, and the study was initiated. Ten plants were randomly assigned to each treatment. Short days (9-h daylength) were initiated at germination (2 weeks after seeding) or 4 or 8 weeks after germination. The duration of SD exposure was 0 (control), 1, 2, 3, or 4 weeks. In addition, plants of each cultivar were grown under continuous SD; all grew poorly, with only three or four leaves $100 \mathrm{~d}$ after germination, and were not included in the analysis. The factorial treatments with three plant stages and five durations of SD were arranged in a completely randomized design. Guard plants were used as outer rows around the plants in the experiment.

The photosynthetic photon flux $(P P F)$ during the 9-h SD photoperiod was $180 \pm 20$ $\mu \mathrm{mol} \cdot \mathrm{m}^{-2} \cdot \mathrm{s}^{-1}$ from natural light supplemented with high-pressure sodium irradiance; $P P F$ during the $16-\mathrm{h} L D$ period was $100 \pm 10$ $\mu \mathrm{mol} \cdot \mathrm{m}^{-2} \cdot \mathrm{s}^{-1}$. The instantaneous $P P F$ was selected to give a similar total of $5.8 \mathrm{~mol} \cdot \mathrm{m}^{-2} \cdot \mathrm{d}^{-1}$ for both the 9- and 16-h daylengths. The temperature was maintained at $21 \pm 2{ }^{\circ} \mathrm{C}$ day/ $/ 8 \pm$ $2{ }^{\circ} \mathrm{C}$ night. The day and night periods for the temperatures followed the 9 -h photoperiod to give an average daily $19^{\circ} \mathrm{C}$. The plants were watered every other day with a fertilizer solution containing $\mathrm{N}$ at $100 \mathrm{mg} \cdot \mathrm{L}^{-1}$ from $15 \mathrm{~N}-$
7P-14K (Peters Professional Peat-Lite Special; The Scotts Co; Marysville, Ohio).

Flowering was recorded when the first bud on the plant showed color. Data on shoot, leaf and flower numbers, leaf area, and dry weight of shoots and roots were collected $105 \mathrm{~d}$ after germination, when the majority of the plants had flowered. The medium was washed off the roots. Dry weights of the plant tissue were determined after $3 \mathrm{~d}$ of drying at $70 \pm 2{ }^{\circ} \mathrm{C}$. Analysis of variance was used to determine main and interaction effects, and polynomial regression to examine differences among treatment means.

\section{Results and Discussion}

Time required for flowering under continuous LD conditions differed significantly among the three cultivars studied. 'Nonstop' was the slowest to develop, requiring $83 \mathrm{~d}$ on average for flowering (Table 1). Flowering in 'Musical' was observed $68 \mathrm{~d}$ from germination (Table 2) and plants of 'Clips' flowered 5 $\mathrm{d}$ later (Table 1). The least significant difference $(P \leq 0.05)$ for average number of LD to flowering among cultivars was $4.1 \mathrm{~d}$.

Variations in rate of flowering among cultivars were anticipated. 'Nonstop' is still considered the standard cultivar for seed-propagated tuberous begonias, although it flowers

Table 1. Effects of duration of exposure to short days (SD, 9-h daylength) on days to flower in Begonia $\times$ tuberhybrida 'Nonstop' and 'Clips'. The remaining development occurred at a 16-h photoperiod.

\begin{tabular}{|c|c|c|}
\hline \multirow{2}{*}{$\begin{array}{l}\text { Duration of SD } \\
\text { (weeks) }\end{array}$} & \multicolumn{2}{|c|}{ Days to flower $\pm \mathrm{SE}$} \\
\hline & Nonstop & Clips \\
\hline 0 & $83 \pm 1.7$ & $78 \pm 1.2$ \\
\hline 1 & $94 \pm 1.4$ & $85 \pm 2.1$ \\
\hline 2 & $95 \pm 1.7$ & $89 \pm 3.0$ \\
\hline 3 & $95 \pm 2.0$ & $89 \pm 2.6$ \\
\hline 4 & $97 \pm 1.8$ & $97 \pm 2.5$ \\
\hline Significance $^{z}$ & $\mathrm{~L}^{* * *}, \mathrm{Q}^{* *}, \mathrm{C}^{*}$ & $\mathrm{~L}^{* * *}$ \\
\hline
\end{tabular}

Table 2. Days to flower in Begonia $\times$ tuberhybrida 'Musical' after exposure to different durations of short days (SD, 9-h daylength) initiated at 0 (early), 4 weeks after germination (intermediate), or 8 weeks after germination (late). The remaining development occurred under a 16-h photoperiod.

\begin{tabular}{|c|c|c|c|}
\hline \multirow{2}{*}{$\begin{array}{l}\text { Duration } \\
\text { of SD } \\
\text { (weeks) }\end{array}$} & \multicolumn{3}{|c|}{$\begin{array}{c}\text { Plant stage } \\
\text { during SD exposure }\end{array}$} \\
\hline & Early & Intermediate & Late \\
\hline & \multicolumn{3}{|c|}{ Days to flower $\pm S E$} \\
\hline 0 & $68 \pm 1.8$ & $68 \pm 1.0$ & $67 \pm 2.4$ \\
\hline 1 & $72 \pm 3.1$ & $70 \pm 1.7$ & $69 \pm 3.0$ \\
\hline 2 & $74 \pm 1.7$ & $68 \pm 0.9$ & $69 \pm 3.0$ \\
\hline 3 & $77 \pm 2.9$ & $79 \pm 2.2$ & $70 \pm 2.6$ \\
\hline 4 & $83 \pm 0.2$ & $82 \pm 3.2$ & $68 \pm 1.0$ \\
\hline \multicolumn{4}{|c|}{ Significance $^{\mathrm{z}}$} \\
\hline Stage & $\mathrm{L}^{* * * *}$ & & \\
\hline Duration & $\mathrm{L}^{* * * *}$ & & \\
\hline
\end{tabular}


Table 3. Mean squares (MS) from analysis of variance for effects of exposure to short days (9-h daylength) initiated 0,4 , or 8 weeks after germination (Stage) for a period of $0,1,2,3$, or 4 weeks (duration) on days to flower in Begonia xtuberhybrida 'Nonstop ', 'Clips', and 'Musical'.

\begin{tabular}{lrccc}
\hline \hline & & \multicolumn{3}{c}{ MS for: } \\
\cline { 3 - 5 } Source & df & Nonstop & Clips & Musical \\
\hline Stage (S) & 2 & 16 & 3 & $526^{* * * *}$ \\
Duration (D) & 4 & $954^{* * *}$ & $1314^{* * * *}$ & $519^{* * * *}$ \\
$\mathrm{~S} \times \mathrm{D}$ & 8 & 27 & 34 & $137^{* *}$ \\
Error & 135 & 93 & 175 & 47 \\
\hline${ }^{* *, * * *}$ Significant at $P \leq 0.01$ or 0.001, respectively.
\end{tabular}

later (Nau, 1993). 'Musical' reportedly develops 10 to $15 \mathrm{~d}$ faster than 'Clips' and flowered 10 d earlier than 'Clips' in our study.

Statistical analyses showed significant effects of length of SD treatment (duration, Table 3) to flower within each cultivar. However, plant stage at the initiation of SD did not affect response in 'Nonstop' and 'Clips'. Data were therefore pooled over stages within each of these cultivars. Rate of development to flowering in 'Musical' was significantly affected by plant stage for initiation of SD. The interaction between SD duration and plant stage was also significant for 'Musical' $(P \leq$ $0.01)$.

Effects of duration of SD on time required for flowering in 'Nonstop' and 'Clips' exhibited significant linear, quadratic, and cubic trends. Ninety-seven days were required for flowering of 'Nonstop' plant with 4 weeks of SD vs. $83 \mathrm{~d}$ for plants under LD. Flowering was delayed linearly with increasing weeks of SD for 'Clips' (Table 1); 4 weeks of SD delayed flowering $19 \mathrm{~d}$ compared with LD.

The stage of development at initiation of SD altered the effect on rate of development in 'Musical' (Table 2). The delay in flowering increased progressively with length of exposure to SD during early development, averaging $15 \mathrm{~d}$ later flowering with 4 weeks of SD. The delay in response was similar whether SD were initiated at germination or 4 weeks later (intermediate plant stage); SD during the final 4 weeks of development did not significantly affect the overall rate of flowering.

Plant size at flowering did not differ significantly among treatments. 'Musical' plants were the largest and 'Nonstop' the smallest of the three cultivars (Table 4). The numbers of leaves and flowers on the main shoot were also greater for 'Nonstop' than for 'Musical'. Although total leaf area was greatest in 'Musical', 'Nonstop' had larger leaves. The average leaf size was $23 \mathrm{~cm}^{2}$ for 'Musical', $45 \mathrm{~cm}^{2}$ for 'Nonstop', and $27 \mathrm{~cm}^{2}$ for 'Clips'.

A higher root/shoot ratio and the formation of tubers have been reported in 'Nonstop' and other tuberous begonias grown under SD (Djurhuus, 1985; Fonteno and Larson, 1982; Oloomi and Payne, 1982). In our study, however, no differences were detected in root dry weight in response to daylength. Shoot dry weight (Table 4) varied among cultivars, but root/shoot ratio was close to one for all three cultivars (data not shown).

In addition to increasing root dry weight,

Table 4. Characteristics at flowering of plants of three cultivars of Begonia $\times$ tuberhybrida.

\begin{tabular}{lcrr}
\hline & & Cultivar \\
\cline { 2 - 4 } Characteristics & Nonstop & Clips & Musical \\
\hline No. shoot & $2 \pm 0.2^{\mathrm{z}}$ & $4 \pm 0.4$ & $5 \pm 0.1$ \\
No. leaves (main shoot) & $8 \pm 0.1$ & $10 \pm 0.4$ & $12 \pm 0.5$ \\
No. flowers (main shoot) & $3 \pm 0.1$ & $4 \pm 0.6$ & $8 \pm 0.9$ \\
Total leaf area $\left(\mathrm{cm}^{2}\right)$ & $485 \pm 56$ & $659 \pm 73$ & $836 \pm 55$ \\
Height (cm) & $12 \pm 0.5$ & $15 \pm 0.4$ & $19 \pm 1.1$ \\
Root dry weight $(\mathrm{g})$ & $2.3 \pm 0.12$ & $2.7 \pm 0.12$ & $2.7 \pm 0.31$ \\
Shoot dry weight $(\mathrm{g})$ & $2.2 \pm 0.13$ & $2.6 \pm 0.34$ & $2.5 \pm 0.47$ \\
\hline
\end{tabular}

\pm SE.

SD were expected to slow development (Djurhuus, 1985; Fonteno and Larson, 1982). Flowering was delayed by exposure to short photoperiods, with the exception of SD applied during late development of 'Musical'. Four weeks of continuous SD may not be sufficient to increase root growth and produce tubers in these tuberous begonias. Peters (1974) suggested that 40-60 SD cycles are required for tuberization. Applying more cycles of SD and allowing the plants to develop beyond initial flowering might have resulted in tuber initiation and development.

Fonteno and Larson (1982) suggested that 'Nonstop' begonia can be in either a growing or a storing developmental phase. The growing phase is characterized by increases in plant size and subsequent flowering. Since flowers form in the leaf axils, flowering in tuberous begonia is dependent on the development of leaves (Heide and Rünger, 1985). Initiation of flowers occurs in both short and long photoperiods (Heide and Rünger, 1985; Kaczperski et al., 1989). Under LD, the terminal growing points remain vegetative and continue to produce leaves. Daylengths $<12 \mathrm{~h}$ should induce partitioning of photosynthates to storage organs, and, eventually, the cessation of leaf formation and top growth (Oloomi and Payne, 1982). In our study, the number of leaves at flowering was similar within cultivars. The observed delay in flowering at SD may have resulted from reduced leaf-unfolding rate and thereby the slower appearance of flowers.

Day and night temperatures affect flowering and tuber formation. Tubers were larger in 'Nonstop' plants grown at day temperatures of $22{ }^{\circ} \mathrm{C}$ compared with $26{ }^{\circ} \mathrm{C}$ (Fonteno and Larson, 1982). Night temperatures $<18{ }^{\circ} \mathrm{C}$ promoted tuber formation in $B . \times$ tuberhybrida 'Karelsk Jomfru', whereas day temperature had no effect (Djurhuus, 1985). A low night temperature is not a prerequisite, however, since tuber formation occurred at $18{ }^{\circ} \mathrm{C}$ night temperature in the study by Fonteno and Larson (1982). Although a lower night temperature may have favored root and tuber development, the lack of tuber formation in our study cannot be attributed to an adverse temperature regime.

Grower recommendations state that SD should be avoided throughout the production of seed-propagated begonias (Kaczperski et al., 1989; Nau, 1993). If plants are grown under natural SD, a change to $\mathrm{LD}$ can be expected to improve flowering and development for most seed-propagated cultivars. Al- though daylength affected rate of flowering, no significant differences were observed in plant morphology at flowering. A higher instantaneous $P P F$ level during a 9-h day appeared as efficient in promoting overall plant growth as the same $P P F$ delivered during a longer day.

Previous studies have concentrated on the effects of SD initiated relatively late in seedling development (10-week-old seedlings in the study by Fonteno and Larson, 1982). In our study, SD were initiated as early as germination, and the results suggest that sensitivity to SD during development varies with cultivar. Plants of 'Musical' were sensitive to photoperiod immediately upon germination and became less sensitive with age, whereas plants of 'Nonstop' and 'Clips' were sensitive to SD throughout their development. Knowing the sensitivity to SD at different stages is necessary to efficiently produce high-quality seedpropagated tuberous begonia.

\section{Literature Cited}

Djurhuus, R. 1985. The effects of photoperiod and temperature on growth and development of $\mathrm{Be}$ gonia $\times$ tuberhybrida 'Karelsk Jomfru'. Scientia Hort. 27:123-131.

Ewart, L.C. 1985. Tuberous rooted begonia, p. 420422. In: J.W. Mastalerz and E.J. Holcomb (eds.). Bedding plants III, a manual on the culture of bedding plants as a greenhouse crop, 3rd ed. Pennsylvania Flower Growers, Harrisburg, Pa.

Fonteno, W.C. and R.A. Larson. 1982. Photoperiod and temperature effects on NonStop tuberous begonia. HortScience 17:899-901.

Fonteno, W.C and R.A. Larson. 1983. Flowering control for NonStop tuberous begonia. North Carolina Flower Growers Bul. 27(3):1-3.

Heide, O.M. and W. Rünger. 1985. Begonia, p. 423. In: A.H. Halevy (ed.). Handbook of flowering, vol. II. CRC Press, Boca Raton, Fla.

Kaczperski, M.P., W.H. Carlson, J. Biernbaum, R. Heins, and L. Ewart. 1989. Producing tuberous begonias from seed. Ext. Bul. E-2136, Michigan State Univ., E. Lansing.

Nau, J. 1993. Ball culture guide: The encyclopedia of seed germination, 2nd ed. Ball Publ., Batavia, Ill.

Oloomi, H. and R.N. Payne. 1982. Effects of photoperiod and pinching on development of Begonia xtuberhybrida. HortScience 17:337-338.

Peters, J. 1974. Einflub der Temperatur auf das oberirdische Wachstum und die Knollenbildung bei Begonia $\times$ tuberhybrida (Voss.). Gartenbauwissenschaft 39:301-308.

Tonecki, J. 1986. Effects of short photoperiod and growth regulators on growth, flowering and tuberization of Begonia xtuberhybrida. Acta Hort. 177:147-156 